\title{
Objectives, methods and content of patient education programmes for adults with asthma: systematic review of studies published between 1979 and 1998
}

\author{
Philippe Sudre, Stéphane Jacquemet, Christophe Uldry, Thomas V Perneger
}

\begin{abstract}
Background-Education programmes for adults with asthma vary widely. Such variability suggests a lack of consensus on what works and what does not. The objectives of this paper are to describe asthma education programmes and assess their variability.
\end{abstract}

Methods-A systematic review of reports published between 1979 and 1998 was conducted. Medline, the CINAHL database, the PsycINFO database, the Cochrane collaboration database, the Dissertation Index database, and cross referencing were used to identify educational interventions; 77 projects including 94 interventions that involved 7953 patients were analysed. A standard form was used to record characteristics of studies (design, setting, size, year, and country of publication), projects (theoretical framework, objectives), and education (methods, duration, intensity, educator, and content).

Results-Most reports did not specify the general (56\%) and educational objectives $(60 \%)$ of the intervention. Important training characteristics were often not available: duration of education (45\%) and number of sessions $(22 \%)$, who delivered education (15\%), whether training was conducted in groups or was individualised $(28 \%)$. When this information was available there were wide variations in training methods and content: training duration ranged from 0 (self-education) to 58 hours and the number of sessions from 0 to 36; training tools such as peak flow meters, diary cards or books were used in various proportions of interventions $(19 \%, 27 \%$, and $23 \%$, respectively). The content of education also differed widely between programmes.

Conclusions-Insufficient documentation of asthma education programmes for adults precludes their replication. This, together with excessive variability, reduces the possibility of identifying their most effective components. A more systematic description of asthma training programmes should be promoted.

(Thorax 1999;54:681-687)

Keywords: asthma; patient education; self-management
Education programmes for people with asthma have existed for a long time but what exactly "patient education" stands for remains elusive. Even a cursory overview of education programmes for asthma patients reveals that programmes vary widely in objectives, educational methods, intensity and duration, educator, and content. Such variability suggests a lack of consensus on what works and what does not in patient education. ${ }^{1}$ It precludes a meaningful evaluation of the overall effectiveness of educating asthma patients such as could be achieved by a meta-analysis. Intervention variability has been a minor concern of previously published reviews. ${ }^{23}$ We therefore conducted a systematic review of published educational interventions for adults with asthma with the objective of describing asthma education programmes and assessing their variability.

\section{Methods}

IDENTIFICATION AND SELECTION OF STUDIES

To identify relevant studies we applied the algorithm "asthma and (education or training or self management)" to the Medline database (1966-98), the Dissertation Index database (1966-98), the Nursing and Allied Health (CINAHL) database (1983-98), the PsycINFO database (1967-98), and the Cochrane collaboration database (fig 1). Titles of 2528 articles archived and of 110 dissertations were screened to select relevant studies and the abstracts of 633 possibly eligible articles were read. Editorials, reviews, and guidelines were kept for cross referencing. After reading 181 potentially relevant articles, 87 studies were excluded because they involved children less than 18 years old exclusively, provided no evidence that an educational intervention was implemented, or were not written in either English, French, Dutch or German. The 94 studies which remained eligible referred to 77 projects as nine projects were described twice, ${ }^{4-21}$ two were described in three publications, ${ }^{22-27}$ and one in five publications. ${ }^{28-32}$ The most complete article in multi-publication projects was kept for this analysis leaving a total of 77 studies. $^{46810121416182022252833-97}$ These studies included a total of 138 intervention groups. Groups that received no or only minimal education ( $n=44$ ) were excluded, leaving a total of 94 active educational interventions. 


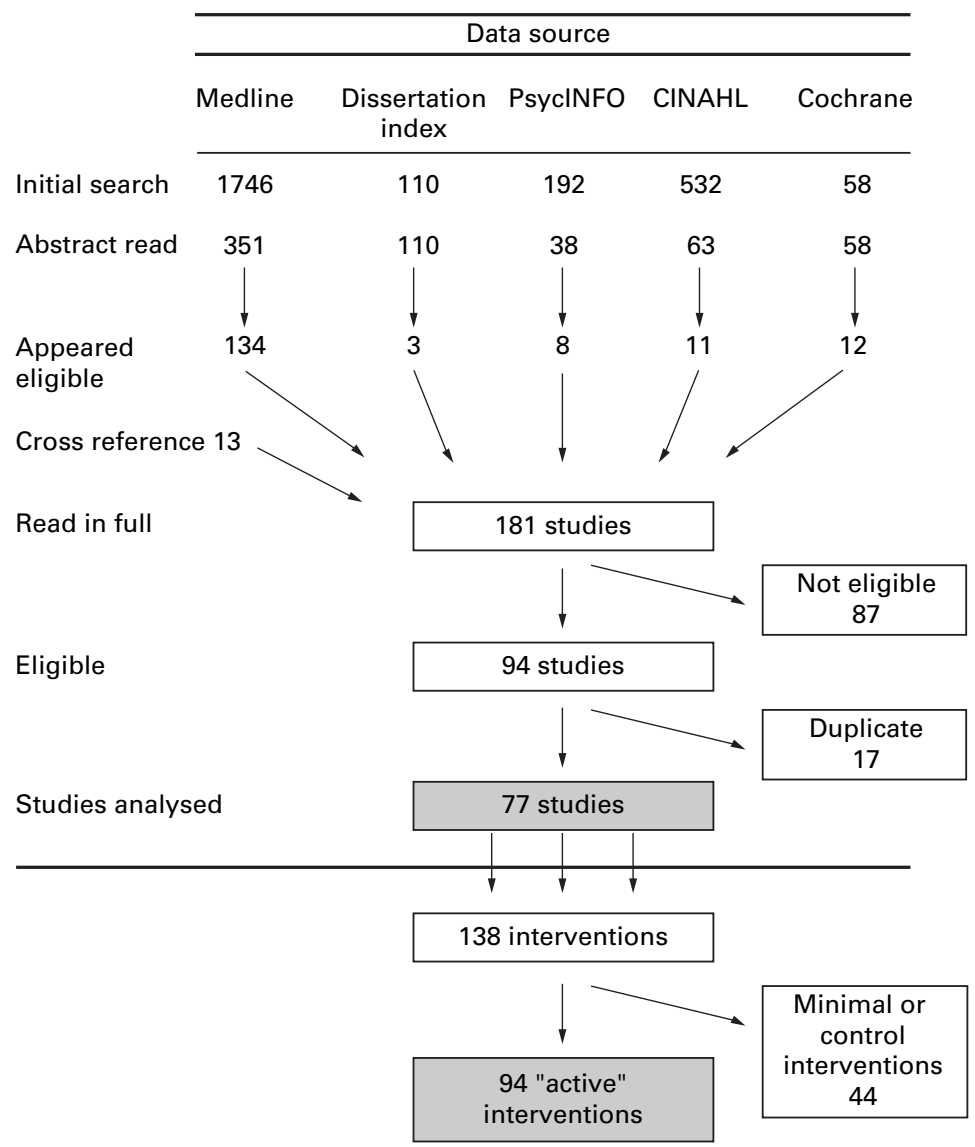

Figure 1 Identification of studies and interventions of asthma education for adults.

DATA COLLECTION INSTRUMENT

We developed and pretested a standard data collection form. For each study we recorded the design, size, setting (inpatient or ambulatory), duration of follow up (if any), date of publication, and country of origin. For each project we noted any reference to a theoretical framework, whether a needs assessment study

Table 1 Characteristics of asthma education studies $(n=77)$

\begin{tabular}{|c|c|c|c|c|c|}
\hline & \multicolumn{5}{|c|}{ Information included } \\
\hline & No. (\%) & Missing (\%) & Mean & Median & Max-min \\
\hline Duration of follow up (weeks) & $69(90)$ & $8(10)$ & 9.8 & 9.0 & $0.25-54$ \\
\hline \multicolumn{6}{|l|}{ Patients } \\
\hline Screened & $18(23)$ & $59(77)$ & 497 & 202 & $30-4400$ \\
\hline Eligible & $24(33)$ & $53(67)$ & 211 & 124 & $14-980$ \\
\hline Enrolled & $72(93)$ & $5(7)$ & 122 & 79 & $5-801$ \\
\hline Analysed & $75(96)$ & $2(4)$ & 106 & 65 & $5-801$ \\
\hline \multicolumn{6}{|l|}{ Year of publication } \\
\hline$<1990$ & $22(29)$ & & & & \\
\hline $1990-1994$ & $25(33)$ & & & & \\
\hline$>1994$ & $30(39)$ & & & & \\
\hline \multicolumn{6}{|c|}{ Recruitment (not known in 4 studies) } \\
\hline Outpatients & $48(62)$ & & & & \\
\hline Inpatients & $10(13)$ & & & & \\
\hline Emergency room & $6(8)$ & & & & \\
\hline Combination of the three & $6(8)$ & & & & \\
\hline Others & $3(5)$ & & & & \\
\hline \multicolumn{6}{|l|}{ Country } \\
\hline North America & $31(42)$ & & & & \\
\hline UK & $15(25)$ & & & & \\
\hline Continental Europe & $19(19)$ & & & & \\
\hline Australia/NZ & $9(12)$ & & & & \\
\hline Other* & $3(2)$ & & & & \\
\hline \multicolumn{6}{|l|}{ Study design } \\
\hline Randomised controlled trial (RCT) & $42(55)$ & & & & \\
\hline Non-RCT & $11(14)$ & & & & \\
\hline Single intervention trial & $24(31)$ & & & & \\
\hline
\end{tabular}

${ }^{\star}$ India (1), Brazil (2). had been conducted, and the objectives of the programme. The methods, setting (individual or group), duration, type of educator, teaching tools, and content were recorded for each educational intervention (there could be more than one per project). Content categories included general information on asthma, triggers, peak flow use, self-management of asthma treatment, psychological aspects of disease, and other. We used the definition of selfmanagement as provided in the articles. Each content category was rated according to three levels of learning: (a) transmission of knowledge, (b) teaching of instrumental skills, and (c) integration of knowledge and skills for selfmanagement of asthma. In addition, we noted whether the education content was generic or individualised - that is, adapted to each patient's context.

DATA COLLECTION PROCEDURE

Each article was abstracted independently by two authors (CU-TVP or PS-SJ). Data collection forms were then checked and compared by data abstractors with a third reviewer (TVP or PS) acting as referee. When initial assessments disagreed the original publication was reexamined and discussed until agreement was reached.

ANALYSIS OF DATA

The characteristics of the 77 projects and 94 interventions were described using frequency distributions. Special attention was paid to missing data. To explore temporal and geographical sources of variability both projects and interventions were compared across year of publication (in approximate tertiles) and continent of origin. Trend tests $\left(\chi^{2}\right.$ or ANOVA depending on dependent variable) were used to test the significance of changes over time.

\section{Results}

STUDIES

Seventy seven projects involving 94 educational interventions and 7953 patients were included. There were 24 single intervention studies, 13 interventions were examined in 11 non-randomised controlled studies, and 57 interventions were assessed in 42 randomised controlled trials; of these 57, 16 compared one intervention with no education (16 interventions), five compared more than one intervention with no intervention (10 interventions), and 21 were without a no-education group (31 interventions).

Most studies were conducted in the USA and the UK and were published in the 1990s (table 1). Most studies failed to provide information on several important variables including the number of screened $(77 \%)$ and eligible $(67 \%)$ patients. There were wide variations in duration of follow up.

THEORETICAL BASIS AND OBJECTIVES

Most projects $(81 \%)$ did not state what educational theory the intervention was based on. Similarly, a patients' needs assessment study was mentioned for only seven projects $(9 \%)$. Intervention objectives stated in terms of 
Table 2 Training characteristics of asthma education interventions $(n=94)$

\begin{tabular}{lrl}
\hline & No. $(\%)^{\star}$ & Not stated (\%) \\
\hline Education delivered by & $34(36)$ & $14(15)$ \\
Physician & $36(38)$ & \\
Nurse & $10(11)$ & \\
Physiotherapist & $9(10)$ & \\
Health educator & $1(1)$ & \\
Multi-disciplinary team & $25(27)$ & \\
Others $\star \star$ & & $26(28)$ \\
Teaching setting & $35(37)$ & \\
Individual & $26(28)$ & \\
Group & $7(7)$ & \\
Both & & \\
Training tools & $22(23)$ & \\
Book & $27(29)$ & \\
Leaflet/handout & $25(27)$ & \\
Diary card & $20(21)$ & \\
Self-management card & $18(19)$ & \\
Peak flow & $14(15)$ & \\
Video tape & $8(9)$ & \\
Audio tape & $6(6)$ & \\
Telephone & $4(4)$ & \\
Others $\star \star \star$ & & \\
Training methods & $83(88)$ & \\
Lecture & $36(38)$ & \\
Discussion with teacher & $24(26)$ & \\
Practical exercise & $17(18)$ \\
Discussion between patients & $5(9)$ & \\
Problem solving & $12(13)$ & \\
Role play & & \\
Others & & \\
& &
\end{tabular}

^For each characteristic the total adds up to more than $100 \%$ as more than one answer is possible.

$\star \star$ Pharmacist (7), self (8), psychotherapist (3), hockey player (1), community health worker (1), yogi (1), experimenter (1), social worker (1), lung technician (1), social scientist (1), unknown (1)

${ }_{\star \star \star}$ Training $\log (1)$, yoga exercise (1), written contract (1), horn in inhaler (1)

"Homework (3), demonstration (2), focus group (1), game (1), training (2), written cues (1), pictorial information (1), asthmatic partner (1).

patient health such as "to improve patient's condition and symptoms" $"$ were explicit in 34 studies (44\%) and learning objectives stated in terms of knowledge, skills or complex behaviours such as "to improve knowledge about asthma" 66 or "to improve self management skill" ${ }^{25}$ were given in 31 studies (40\%).

\section{EDUCATION CHARACTERISTICS}

Even basic descriptive information was often missing (table 2). For example, information about who delivered the education (15\%), whether education was conducted individually or in a group $(28 \%)$, and what teaching tools were used $(13 \%)$ was missing in a substantial proportion of reports. When information was available it revealed important variability in training characteristics. Education was most often delivered by nurses and/or physicians; the patients educated themselves using a book or some other training tool $9 \%$ of the time. Delivery of education by a multi-disciplinary team was mentioned in one intervention only, ${ }^{4}$ although more than one health professional was involved in 30 interventions (32\%). Individual education was slightly more common $(37 \%)$ than group settings $(28 \%)$. Most interventions relied on vertical teaching (defined as the unidirectional delivery of an educational message from a teacher to a student without reference to any interaction), and about half used interactive approaches (i.e. discussion).

The duration of formal interaction with educators was missing for 42 interventions (45\%); when available, duration ranged from 0 to 58 hours (mean 6.8 hours, median 3 hours, 0 hour denotes self-education only). The number of days over which the educational intervention was delivered was missing for 23 interventions (25\%); when specified, the period ranged from 0 (self-education) to 1080 days (mean 108.8 days, median 30 days). The number of education sessions was missing for 21 interventions $(22 \%)$; when specified, the number ranged

Table 3 Content and level of integration of 94 asthma education interventions

\begin{tabular}{|c|c|c|c|c|c|}
\hline \multirow[b]{2}{*}{ Content } & \multicolumn{4}{|c|}{ Level of integration * } & \multirow[b]{2}{*}{$\begin{array}{l}\text { Personalisation } \\
\text { No. (\%) }\end{array}$} \\
\hline & $\begin{array}{l}\text { Knowledge } \\
\text { No. }(\%)\end{array}$ & $\begin{array}{l}\text { Skills } \\
\text { No. (\%) }\end{array}$ & $\begin{array}{l}\text { Integration } \\
\text { No. }(\%)\end{array}$ & $\begin{array}{l}\text { Any } \\
\text { No. (\%) }\end{array}$ & \\
\hline Asthma disease & & & & $64(68)$ & \\
\hline General knowledge of asthma & $44(47)$ & - & - & $44(47)$ & - \\
\hline Physiopathology & $41(44)$ & - & - & $41(44)$ & - \\
\hline Symptoms (general) & $28(30)$ & - & - & $15(21)$ & $4(4)$ \\
\hline Symptoms monitoring & $13(14)$ & $11(12)$ & - & $24(26)$ & $3(3)$ \\
\hline Experience of asthma & $11(12)$ & - & - & $11(12)$ & $3(3)$ \\
\hline Symptoms management and control & $22(23)$ & $5(5)$ & $5(5)$ & $32(34)$ & $7(7)$ \\
\hline Drugs & & & & $78(83)$ & \\
\hline Use of drugs in general & $54(57)$ & - & - & $54(57)$ & - \\
\hline Type of drugs (BD/AI) & $55(58)$ & - & - & $55(58)$ & $15(16)$ \\
\hline Inhalation devices, general & $17(18)$ & $31(33)$ & - & $48(51)$ & $14(15)$ \\
\hline Compliance (chronic) & $18(19)$ & - & $1(1)$ & $19(20)$ & $2(2)$ \\
\hline Self-adjustment (acute episode) & $23(34)$ & - & $8(9)$ & $40(43)$ & $11(12)$ \\
\hline Triggers & & & & $28(39)$ & \\
\hline List, general & $37(39)$ & - & - & $37(39)$ & $2(3)$ \\
\hline Avoidance/eviction & $25(27)$ & $1(1)$ & $4(4)$ & $30(32)$ & $9(10)$ \\
\hline Peak flow & & & & $45(50)$ & \\
\hline Peak flow practice & $24(26)$ & $4(4)$ & - & $28(30)$ & $4(4)$ \\
\hline Peak flow use & $20(21)$ & $15(16)$ & $6(6)$ & $41(43)$ & $8(8)$ \\
\hline Self-management (SM) & & & & $52(55)$ & \\
\hline $\mathrm{SM}$ in general & $32(34)$ & - & - & $32(34)$ & $6(6)$ \\
\hline SM plan & $26(28)$ & - & $4(4)$ & $30(32)$ & $18(19)$ \\
\hline Others & & & & $52(55)$ & \\
\hline Disease perception/psychological & $14(15)$ & - & $4(4)$ & $18(19)$ & $8(9)$ \\
\hline Social support & $4(4)$ & - & $1(1)$ & $5(7)$ & $0(0)$ \\
\hline Relaxation, self-control, yoga, etc. & $11(12)$ & $7(7)$ & $3(3)$ & $21(22)$ & $5(5)$ \\
\hline Smoking & $8(9)$ & $1(1)$ & $0(0)$ & $9(10)$ & $3(3)$ \\
\hline
\end{tabular}

- = not applicable $; \mathrm{BD} / \mathrm{AI}=$ bronchodilator/anti-inflammatory.

*Level of integration: content category is rated according to levels of learning as either the simple transmission of knowledge, teaching of instrumental skills, or the integration of knowledge and skills for self-management of asthma. 
Table 4 Characteristics of asthma education studies $(n=77)$ and interventions $(n=94)$ by year

\begin{tabular}{|c|c|c|c|c|}
\hline \multirow[b]{2}{*}{ Study characteristics } & \multicolumn{3}{|l|}{ Year } & \multirow[b]{2}{*}{$p$ value ${ }^{\star}$} \\
\hline & $\begin{array}{l}1979-89 \\
(n=22)\end{array}$ & $\begin{array}{l}1990-94 \\
(n=25)\end{array}$ & $\begin{array}{l}1995-98 \\
(n=30)\end{array}$ & \\
\hline Mean (SE) no. of patients studied & $68(17)$ & $170(37)$ & $79(11)$ & 0.01 \\
\hline Randomised study (\%) & $10(46)$ & $13(52)$ & $19(63)$ & 0.19 \\
\hline Intervention characteristics (\%) & $n=28$ & $n=31$ & $n=35$ & \\
\hline \multicolumn{5}{|l|}{ Hours of training } \\
\hline Mean (SE) & $8.4(3.6)$ & $4.3(1.5)$ & $7.8(2.6)$ & 0.51 \\
\hline $\mathrm{n}$ & 13 & 17 & 22 & \\
\hline \multicolumn{5}{|l|}{ Duration of training period (days) } \\
\hline Mean (SE) & $48.7(24.6)$ & $78.5(28.1)$ & $173.2(45.3)$ & 0.05 \\
\hline $\mathrm{n}$ & 20 & 22 & 29 & \\
\hline \multicolumn{5}{|l|}{ Training tools $(\%)$} \\
\hline Book & $6(21)$ & $6(19)$ & $10(29)$ & 0.48 \\
\hline Diary card & $4(14)$ & $5(16)$ & $16(46)$ & 0.01 \\
\hline Self-management card & $3(11)$ & $5(16)$ & $12(34)$ & 0.02 \\
\hline Peak flow & $1(4)$ & $6(19)$ & $11(31)$ & 0.01 \\
\hline Others & $4(14)$ & $3(10)$ & $6(17)$ & 0.71 \\
\hline Mean (SE) number of tools & $1.3(0.2)$ & $1.3(0.2)$ & $2.3(0.2)$ & $<0.01$ \\
\hline \multicolumn{5}{|l|}{ Training methods (\%) } \\
\hline Lecture (vertical) & $23(82)$ & $29(93)$ & $31(89)$ & 0.48 \\
\hline Interaction $\star \star$ & $17(60)$ & $11(36)$ & $20(57)$ & 0.89 \\
\hline \multicolumn{5}{|l|}{ Content $(\%)$} \\
\hline Self-management & $10(36)$ & $15(48)$ & $27(77)$ & $<0.01$ \\
\hline Peak flow & $6(21)$ & $12(39)$ & $27(77)$ & $<0.01$ \\
\hline Trigger & $5(18)$ & $18(58)$ & $25(71)$ & $<0.01$ \\
\hline Personalisation & $13(46)$ & $12(39)$ & $18(51)$ & 0.65 \\
\hline
\end{tabular}

${ }^{\star} \chi^{2}$ for trend (proportion) or ANOVA (means).

${ }^{\star}$ Either problem solving, discussion with teacher or between patients, practical exercise, or role play.

from 0 (self-education) to 36 sessions (mean 4.2 sessions, median 3 sessions).

CONTENT OF PATIENT EDUCATION

Education content was often insufficiently described. Available information indicated that interventions varied widely (table 3 ). At least some aspect of training was personalised in $46 \%$ of interventions. The most common content categories included asthma as a disease and drugs. Few interventions went beyond transmission of knowledge.

TRENDS OVER TIME

Programme characteristics changed little over time (table 4). Studies grew bigger in the 1990-4 period and a slight tendency toward more randomised evaluations in recent years was not statistically significant. The mean duration of the training period increased from less than two months to almost six ( $p=0.02)$, suggesting that one-time interventions are falling out of favour. More recent programmes were more likely to use diary cards and peak flow meters as training tools, and to include a discussion of triggers of asthma attacks, peak flow use, and self-management. Neither interactive teaching methods nor personalised training became more common in recent years.

GEOGRAPHICAL DIFFERENCES

Training was more often individualised in programmes from North America, Australia or New Zealand and relied more often on nurses to deliver education in North America and the UK. All programmes from Oceania addressed the use of peak flow meters while this component was included in only about one third of interventions conducted elsewhere (table 5).

\section{Discussion}

This systematic review identified 77 projects describing or comparing 94 educational interventions for adults with asthma. The main findings are that important information about the educational programmes is often lacking in the published sources, and that educational interventions vary widely in their methods and content. Furthermore, far too many programmes are potentially ineffective as they rely on mere transmission of knowledge in the hope of modifying behaviour and resort to vertical teaching methods which may lack effectiveness when educating adults. ${ }^{98} 99$

\section{VARIABILITY IN PRACTICES}

The variations between programmes were often impressive. For instance, patient education could consist of a 10 minute encounter with a physician ${ }^{65}$ or a 24 hour, week long, programme involving several trainers ${ }^{29}$; it may have been a single session or a series of classes spread over two years. ${ }^{20}$ Training could be individual, in groups, or both and use any combination of tools and education methods. Even the content of patient education varied widely: only $58 \%$ of the interventions addressed the difference between anti-

Table 5 Characterisation of asthma education intervention $\left(n=91^{\star}\right)$ by region

\begin{tabular}{|c|c|c|c|c|c|}
\hline & $\begin{array}{l}\text { North America } \\
(n=41)\end{array}$ & $\begin{array}{l}\text { Australia } \mathcal{E} \\
\text { New Zealand } \\
(n=9)\end{array}$ & $\begin{array}{l}\text { United Kingdom } \\
(n=19)\end{array}$ & $\begin{array}{l}\text { Mainland } \\
\text { Europe } \\
(n=22)\end{array}$ & $p$ value ${ }^{\star *}$ \\
\hline \multicolumn{6}{|l|}{ Hours of training } \\
\hline Mean (SE) & $6.6(2.2)$ & $6.2(1.7)$ & $2.9(1.9)$ & $8.4(3.8)$ & 0.70 \\
\hline $\mathrm{n}$ & 20 & 6 & 9 & 15 & \\
\hline \multicolumn{6}{|l|}{ Education delivered by (\%) } \\
\hline Physician & $7 \quad(17)$ & $3 \quad(33)$ & $12 \quad(63)$ & $10 \quad(46)$ & 0.01 \\
\hline Nurse & $19 \quad(46)$ & $1 \quad(11)$ & $9 \quad(47)$ & $7 \quad(32)$ & 0.18 \\
\hline \multicolumn{6}{|l|}{ Training tools (\%) } \\
\hline Diary card & $12 \quad(29)$ & $4 \quad(44)$ & $4 \quad(21)$ & $4 \quad(18)$ & 0.44 \\
\hline Peak flow & $5 \quad(12)$ & 3 (33) & $7 \quad(37)$ & $3(14)$ & 0.09 \\
\hline Self-management card & $7 \quad(17)$ & $2 \quad(22)$ & $8 \quad(42)$ & 3 (14) & 0.11 \\
\hline Mean (SE) number of tools & $1.9(0.2)$ & $1.9(0.4)$ & $1.7(0.3)$ & $1.9(0.1)$ & 0.74 \\
\hline \multicolumn{6}{|l|}{ Training methods (\%) } \\
\hline Vertical & $38 \quad(93)$ & $7 \quad(78)$ & $16 \quad(84)$ & $19 \quad(86)$ & 0.56 \\
\hline Interaction $\star \star \star \star$ & $26 \quad(63)$ & $6 \quad(67)$ & $5(26)$ & $8 \quad(36)$ & 0.01 \\
\hline \multicolumn{6}{|l|}{ Content $(\%)$} \\
\hline Peak flow & $16 \quad(39)$ & $9 \quad(100)$ & $7 \quad(37)$ & $12 \quad(55)$ & 0.01 \\
\hline Self-management & $22 \quad(53)$ & $6 \quad(67)$ & $14 \quad(74)$ & $8 \quad(36)$ & 0.10 \\
\hline
\end{tabular}

$\star$ Three studies from India (1) and Brazil (2) are excluded from this table.

$\star \star \chi^{2}$ test for proportion or ANOVA (means).

$\star \star \star$ Either problem solving, discussion with teacher or between patients, practical exercise, or role play. 
inflammatory drugs and bronchodilators, and only one third proposed a complete selfmanagement plan to the participants.

This finding suggests a lack of consensus on effective patient education in asthma. Either effectiveness data are not available, or they are but people are not using them. Establishing a formal consensus on what works in patient education in asthma and encouraging research about what is unknown should be a priority for physicians, educators, purchasers, and policy makers. Historically, the description of variations in clinical practice has provided a useful impetus for fostering consensus, encouraging relevant outcomes research, and eliminating care of uncertain effectiveness. ${ }^{100}$ However, until consensus is reached and effectiveness demonstrated, education programmes for patients with asthma will face low credibility, limited funding, and limited eligibility for reimbursement by purchasers and health insurance funds.

The variability in educational interventions implies that a meta-analysis of the overall effectiveness of patient education in asthma is hardly feasible; the heterogeneity of the interventions precludes meaningful pooling of the results. A meta-analysis to identify predictors of effectiveness among educational interventions would be more useful but even that endeavour would be hampered by the variability in outcome variables used in the various studies (unpublished observation based on randomised trials included in our analysis).

We are concerned that many of the educational interventions that we reviewed may lack effectiveness because they conflict with leading theories of adult education. ${ }^{99}$ Most interventions had no clear theoretical foundation, nor were they based on empirical evidence of patient needs. Most aimed at transmitting knowledge about asthma instead of focusing on the patient's ability to deal with her or his illness, but ample evidence suggests that a wide gap often separates knowledge and behaviour. ${ }^{98}$ Educational methods were also often ill suited, favouring the vertical teaching format, while interactive methods and problem based learning were often woefully absent. Even though these a priori arguments do not demonstrate lack of effectiveness, they raise serious concerns about the current state of patient education for subjects with asthma.

INCOMPLETE DOCUMENTATION

This systematic retrieval of information from published reports uncovered another difficulty: many programmes are so poorly described that, even if they were effective, one could not replicate them in another setting. Thus, educational interventions are not up to the standard routinely applied to pharmacological treatments for which the indication, dosage, route of administration, number of administrations per day, duration of treatment, etc must be specified. Furthermore, studies often failed to describe what types of patients were recruited or the participation rates among eligible patients, which prevents the reader from assessing the applicability of the findings to another patient population. Incomplete pro- gramme description may be due to the limited space that journals provide for authors and programme manuals might have been available for several studies. In general, however, the article length allowed in most journals should be sufficient to present the information required for reproducing an intervention. Lack of transmissibility obviously hampers progress and our observation that little has changed over time in patient education suggests that, indeed, educators are not able to benefit from the experience of others. We recommend that a consensus be developed about what information should appear in published descriptions and evaluations of educational interventions (akin to the CONSORT statement for clinical trials ${ }^{101}$ ) to promote the sharing of experience and facilitate the replication of evaluation studies. In our opinion the standard description should specify a theoretical framework for the intervention, distinguish between general objectives (in terms of patient health) and specific objectives (referring to the educational process), and provide a detailed account of what was done.

As all systematic reviews, our study is subject to a possible publication bias and our conclusions cannot apply to programmes that have not been published. However, even if published interventions were not representative of the rest, the variability between interventions and their insufficient documentation would remain a valid observation which requires prompt corrective action.

Source of funding: Swiss National Science Foundation (grant no. 32-39720.93)

The authors would like to acknowledge the assistance and express their gratitude to Ms Aude Jaccard for her invaluable help in database search and reference identification.

1 Gibson PG, Coughlan J, Wilson AJ, et al. The effects of limited (information only) patient education programs on the health 2 Bernard Bonnin AC, Stachenko S, Bonin D, et al. Self-management teaching programs and morbidity of Self-management teaching programs and morbidity of
pediatric asthma: a meta-analysis. $\mathcal{F}$ Allergy Clin Immunol 1995;95:34-41

3 Devine EC. Meta-analysis of the effects of psychoeducational care in adults with asthma. Res Nurs Health 1996;19: $367-76$

4 Cox NJ, Hendricks JC, Binkhorst RA, et al. A pulmonary rehabilitation program for patients with asthma and mild
chronic obstructive pulmonary diseases (COPD). Lung 1993;171:235-44

5 Cox NJ, Hendriks J, Binkhorst RA, et al. Favorable effects of rehabilitation in patients with CARA. Ned Tijdschr Geneeskd 1991;135:987-91.

6 Bailey WC, Richards JM Jr, Brooks CM, et al. A randomized trial to improve self-management practices of adults with trial to improve self-management practices
asthma. Arch Intern Med 1990;150:1664-8.

7 Windsor RA, Bailey WC, Richards JM Jr, et al. Evaluation of the efficacy and cost effectiveness of health education methods to increase medication adherence among adults methods to increase medication adherence among
with asthma. Am f Public Health 1990;80:1519-21.

8 Charlton I, Charlton G, Broomfield J, et al. An evaluation of a nurse-run asthma clinic in general practice using an attitudes and morbidity questionnaire. Fam Pract 1992;9:15460.

9 Charlton I, Charlton G, Broomfield J, et al. Audit of the effect of a nurse run asthma clinic on workload and patient morbidity in a general practice. Br f Gen Pract 1991;41: $227-31$

10 Coté J, Cartier A, Robichaud P, et al. Influence on asthma morbidity of asthma education programs based on self-management plans following treatment optimization. Am $\mathcal{F}$ Respir Crit Care Med 1997;155:1509-14.

11 Coté J, Cartier A, Malo JL, et al. Compliance with peak expiratory flow monitoring in home management of asthma. Chest 1998;113:968-72.

12 Bolton MB, Tilley BC, Kuder J, et al. The cost and effectiveness of an education program for adults who have effectiveness of an education program for

13 Ford ME, Havstad SL, Tilley BC, et al. Health outcomes among African American and Caucasian adults following a 
randomized trial of an asthma education program. Ethn Health 1997;2:329-39.

14 Lahdensuo A, Haahtela T, Herrala J, et al. Randomised comparison of guided self management and traditional treatment of asthma over one year. BMF 1996;312:748-52.

15 Lahdensuo A, Haahtela T, Herrala J, et al. Randomised comparison of cost effectiveness of guided self manage-
ment and traditional treatment of asthma in Finland. BMF 1998;316:1138-9.

16 Knoell DL, Pierson JF, Marsh CB, et al. Measurement of outcomes in adults receiving pharmaceutical care in a comprehensive asthma outpatient clinic. Pharmacotherapy 1998;18:1365-74.

17 Pierson JF. Health outcome and satisfaction among asthme patients: application to a pharmaceutical care educational interpatients: application to a pharmaceutical care
vention. The Ohio State University, 1997.

18 Wilson SR, Scamagas P, German DF, et al. A controlled trial of two forms of self-management education for adults with asthma. Am F Med 1993;94:564-76.

19 Wilson-Pessano SR, Scamagas P, Arsham GM, et al. An evaluation of approaches to asthma self-management education for adults: the air/kaiser-permanente study. Health Educ $Q$ 1987; 14:333-43.

20 Kelso TM, Abou Shala N, Heilker GM, et al. Comprehensive long-term management program for asthma: effect on outcomes in adult African-Americans. Am $\mathcal{F}$ Med Sci 1996; 311:272-80.

21 Kelso TM, Self TH, Rumbak MJ, et al. Educational and long-term therapeutic intervention in the ED: effect on outcomes in adult indigent minority asthmatics. $A m \mathcal{F}$ Emerg Med 1995;13:632-7.

22 Huss K, Squire EN Jr, Carpenter GB, et al. Effective education of adults with asthma who are allergic to dust mites. $\mathcal{F}$ Allergy Clin Immunol 1992;89:836-43.

23 Huss K, Huss RW, Squire EN, et al. Computer education for asthmatics: what effects? F Nurs Care Oual 1992;6:57-66.

24 Huss K, Salerno M, Huss RW. Computer-assisted reinforcement of instruction: effects on adherence in adult atopic asthmatics. Res Nurs Health 1991;14:259-67.

25 D'Souza W, Burgess C, Ayson M, et al. Trial of a "credit card" asthma self-management plan in a high-risk group of
patients with asthma. F Allergy Clin Immunol 1996;97: patients

26 Beasley R, D'Souza W, Te Karu H, et al. Trial of an asthma action plan in the Maori community of the Wairarapa. $N Z$ Med F 1993;106:336-8

27 D'Souza WJ, Te Karu H, Fox C, et al. Long-term reduction in asthma morbidity following an asthma self-management programme. Eur Respir f 1998;11:611-6.

28 Muhlhauser I, Richter B, Kraut D, et al. Evaluation of a structured treatment and teaching programme on asthma. f Intern Med 1991;230:157-64.

29 Worth H. Patient education in asthmatic adults. Lung 1990; 168(Suppl):463-8.

30 Worth $\mathrm{H}$. Patient education in asthmatic adults. Monald Arch Chest Dis 1993;48:155-8.

31 Trautner C, Richter B, Berger M. Cost-effectiveness of a structured treatment and teaching programme on asthma. Eur Respir F 1993;6:1485-91

32 Worth H. Patient education in the treatment of bronchial asthma: goals, content, pedagogic technics and evaluation of a structured program. Fortschr Med 1989;107:631-5.

33 Maiman LA, Green LW, Gibson G, et al. Education for selftreatment by adult asthmatics. $7 A M A$ 1979;241:1919-22.

34 Moldofsky H, Broder I, Davies G, et al. Videotape educational program for people with asthma. Can Med Assoc $\mathcal{F} 1979 ; \mathbf{1 2 0} 669-72$.

35 Shim C, Williams MH. The adequacy of inhalation of aerosol from canister nebulizers. Am ₹ Med 1980;69:891-4.

36 Darr MS, Self TH, Ryan MR, et al. Content and retention evaluation of an audiovisual patient-education program on evaluation of an audiovisual patient-education progr
bronchodilators. Am f Hosp Pharm 1981;38:672-5.

37 O'Bey KA, Jim LK, Gee JP, et al. An education program that improves the psychomotor skills needed for metaprotereno inhaler use. Drug Intell Clin Pharm 1982;16:945-8.

38 Roberts RJ, Robinson JD, Doering PL, et al. A comparison of various types of patient instuction in the proper administation of metered inhalers. Drug Intell Clin Pharn 1982;16:53-5, 59

39 Self TH, Brooks JB, Lieberman P, et al. The value of demonstration and role of the pharmacist in teaching the correct use of pressurized bronchodilators. Can Med Assoc f 1983;128:129-31.

40 Nagarathna R, Nagendra HR. Yoga for bronchial asthma: a controlled study. BMF Clin Res Ed 1985;291:1077-9.

41 Hilton S, Sibbald B, Anderson HR, et al. Controlled evaluation of the effects of patient education on asthma morbidity in general practice. Lancet 1986;i:26-9.

42 Deter HC. Cost-benefit analysis of psychosomatic therapy in asthma. $\mathcal{F}$ Psychosom Res 1986;30:173-82.

43 Partridge MR. Asthma education: more reading or more viewing? $\mathcal{F} R$ Soc Med 1986;79:326-8.

44 Snyder SE, Winder JA, Creer TJ. Development and evaluation of an adult asthma self-management program: wheezers anonymous. $\mathcal{F}$ Asthma 1987;24:153-8.

45 Heringa P, Lawson L, Reda D. The effect of a structured education program on knowledge and psychomotor skills of patients using beclomethasone dipropionate aerosol for of patients using beclomethasone dipropionate aerosol for

46 Jones PK, Jones SL, Katz J. Improving compliance for asthmatic patients visiting the emergency department using a
health belief model intervention. F Asthma 1987;24:199206.
47 Jenkinson D, Davison J, Jones S, et al. Comparison of effects of a self management booklet and audiocassette for patients with asthma BMY 1988;297:267-70.

48 Janson Bjerklie S, Shnell S. Effect of peak flow information on patterns of self-care in adult asthma. Heart Lung 1988; 17:543-9.

49 Maes S, Schlosser M. Changing health behaviour outcomes in asthmatic patients: a pilot intervention study. $\mathrm{Soc} S \mathrm{Sc}$ Med 1988;26:359-64.

50 Beasley R, Cushley M, Holgate ST. A self management plan in the treatment of adult asthma. Thorax 1989;44:200-4.

51 Tehan N, Sloane B, Walsh-Robart N, et al. Impact of asthma self-management education on the health behavior of young adults. A pilot study of the Dartmouth College "Breathe Free" program. F Adolesc Health Care 1989;10: 513-9.

52 Bauman AE, Craig AR, Dunsmore J, et al. Removing barriers to effective self-management of asthma. Patient Educ Couns 1989;14:217-26.

53 Charlton I, Charlton G, Broomfield J, et al. Evaluation of peak flow and symptoms only self management plans for control of asthma in general practice. BMF 1990;301: $1355-9$.

54 Mayo PH, Richman J, Harris HW. Results of a program to reduce admissions for adult asthma. Ann Intern Med 1990; 112:864-71.

55 Ringsberg KC, Wiklund I, Wilhelmsen L. Education of adult patients at an "asthma school": effects on quality of life, knowledge and need for nursing. Eur Respir $\mathcal{7}$ 1990;3: 33-7.

56 Reeder KP, Dolce JJ, Duke L, et al. Peak flow meters: are they monitoring tools or training devices? $\mathcal{F}$ Asthma 1990;27:219-27

57 Cochrane LM, Clark CJ. Benefits and problems of a physical training programme for asthmatic patients. Thorax 1990;45:345-51.

58 Reinert M, Steurich F. What does the asthmatic patient know about his disease? Pneumologie 1990;44(Suppl 1):112-3.

59 Lirsac B, Braunstein G. Randomized evaluation of two teaching methods using aerosol dosers. Rev Mal Respir 991;8:559-65.

60 Haber P, Sachs G, Roggla G, et al. Effect of structured ambulatory training of patients with chronic respiratory tract diseases on the efficiency of long-term care. Wien Klin Wochenschr 1991;103:605-11.

61 Barritt PW, Staples EB. Measuring success in asthma care: a repeat audit. Br F Gen Pract 1991;41:232-6.

62 Byrne DM, Drury J, Mackay RC, et al. Evaluation of the efficacy of an instructional programme in the selfmanagerne

63 Yoon R, McKenzie DK, Bauman A, et al. Controlled trial evaluation of an asthma education programme for adults. Thorax 1993;48:1110-6.

64 Dzyngel B, Kesten S, Chapman KR. Assessment of an ambulatory care asthma program. F Asthma 1994;31:291300 .

65 Osman LM, Abdalla MI, Beattie JA, et al. Reducing hospital admission through computer supported education for asthma patients. Grampian Asthma Study of Integrated Care (GRASSIC). BMF 1994;308:568-71.

66 Thapar A. Educating asthmatic patients in primary care: a pilot study of small group education. Fam Pract 1994;11: 39-43.

67 Grampian Asthma Study of Integrated Care (GRASSIC). Effectiveness of routine self monitoring of peak flow in Effectiveness of routine self monitoring of
patients with asthma. BMF 1994;308:564-7.

68 D'Souza W, Crane J, Burgess C, et al. Community-based asthma care: trial of a "credit card" asthma selfmanagement plan. Eur Respir f 1994;7:1260-5.

69 Garrett J, Fenwick JM, Taylor G, et al. Prospective controlled evaluation of the effect of a community based asthma education centre in a multiracial working class neighbourhood. Thorax 1994;49:976-83.

70 Boulet LP, Boutin H, Cote J, et al. Evaluation of an asthma self-management education program. F Asthma 1995;32: $199-206$.

71 Pauley TR, Magee MJ, Cury JD. Pharmacist-managed, physician-directed asthma management program reduces emergency department visits. Ann Pharmacother 1995;29: 5-9.

72 Brewin AM, Hughes JA. Effect of patient education on asthma management. Br f Nurs 1995;4:81-101.

73 Kotses H, Bernstein IL, Bernstein DI, et al. A selfmanagement program for adult asthma. Part I: Development and evaluation. F Allergy Clin Immunol 1995;95:52940

74 Ignacio Garcia JM, Gonzalez Santos P. Asthma selfmanagement education program by home monitoring of peak expiratory flow. Am F Respir Crit Care Med 1995;151: 353-9.

75 Allen RM, Jones MP, Oldenburg B. Randomised trial of an asthma self-management programme for adults. Thorax 1995;50:731-8

76 Jones KP, Mullee MA, Middleton M, et al. Peak flow based asthma self-management: a randomised controlled study in general practice. British Thoracic Society Research Committee. Thorax 1995;50:851-7.

77 Verver S, Poelman M, Bogels A, et al. Effects of instruction by practice assistants on inhaler technique and respiratory symptoms of patients. A controlled randomized videotaped intervention study. Fam Pract 1996;13:35-40. 
78 Kotses H, Stout C, McConnaughy K, et al. Evaluation of individualized asthma self-management programs. $\mathcal{f}$ individualized asthma

79 Ayres JG, Campbell LM. A controlled assessment of an asthma self-management plan involving a budesonide dose regimen. OPTIONS Research Group. Eur Respir 7 1996;9: 886-92.

80 Emtner M, Hedin A, Stalenheim G. Asthmatic patients' views of a comprehensive asthma rehabilitation programme: a three-year follow-up. Physiother Res Int 1998;3:175-93.

81 Kauppinen R, Sintonen H, Tukiainen H. One-year economic evaluation of intensive vs conventional patient education and supervision for self-management of new asthmatic patients. Respir Med 1998;92:300-7.

82 Ghosh CS, Ravindran P, Joshi M, et al. Reductions in hospital use from self management training for chronic asthmatics. Soc Sci Med 1998;46:1087-93.

83 Klein JJ, van der Palen J, van den Hof S, et al. Self-treatment by adults during slow-onset exacerbations of asthma. by adults during slow-onset exacer Couns 1997;32:S61-6.

84 Dickinson J, Hutton S, Atkin A, et al. Reducing asthma morbidity in the community: the effect of a targeted nurserun asthma clinic in an English general practice. Respir Med 1997;91:634-40.

85 Turner MO, Taylor D, Bennett $\mathrm{R}$, et al. A randomized trial comparing peak expiratory flow and symptom selfmanagement plans for patients with asthma attending primary care clinic. Am $\mathcal{F}$ Respir Crit Care Med 1998;157: 540-6.

86 Cowie RL, Revitt SG, Underwood MF, et al. The effect of a peak flow-based action plan in the prevention of exacerbations of asthma. Chest 1997;112:1534-8.

87 de Oliveira MA, Bruno VF, Ballini LS, et al. Evaluation of an educational program for asthma control in adults. F Asthma 1997;34:395-403.

88 Berg J, Dunbar-Jacob J, Sereika SM. An evaluation of a selfmanagement program for adults with asthma. Clin Nurs Res 1997;6:225-38.
89 van der Palen J, Klein JJ, Rovers MM. Compliance with inhaled medication and self-treatment guidelines following self-management programme in adult asthmatics. Eur Respir F 1997;10:652-7.

90 Mulloy E, Donaghy D, Quigley C, et al. A one-year prospective audit of an asthma education programme in an outpatient setting. Irish Med f 1996;89:226-8.

91 Martindale H. Evaluation of an asthma education programme. NZ F Physiother 1984;23-4.

92 Bauman AE, Craig AR, Dunsmore J, et al. Removing barriers to effective self-management of asthma. Patient Educ Couns 1989;14:217-26.

93 Simonian YH. The efficacy of education and resilience training on asthma patients' self-management and quality of life. University of Utah, 1998 .

94 Sommaruga M, Spanevello A, Migliori GB, et al. The effects of a cognitive behavioural intervention in asthmatic patients. Monaldi Arch Chest Dis 1995;50:398-402.

95 Neri M, Migliori GB, Spanevello A, et al. Economic analysis of two structured treatment and teaching programs on asthma. Allergy 1996;51:313-9.

96 Aiolfi S, Confalonieri M, Scartabellati A, et al. International guidelines and educational experiences in an outpatient

for asthma. Monaldi Arch Chest Dis 1995;50:477-81

Zeiger RS, Heller S, Mellon MH, et al. Facilitated referral to asthma specialist reduces relapses in asthma emergency room visits. F Allergy Clin Immunol 1991;87:1160-8 (published erratum appears in $\mathcal{F}$ Allergy Clin Immunol 1992;90:278)

98 Gagné RM. The conditions of learning. New York: Holt, Rinehart and Winston, 1970.

99 Knowles M. The modern practice of adult education: andragogy vs pedagogy. New York: Association Press, 1970.

100 Detzsky AS. Regional variation in medical care. $N$ Engl $\mathcal{F}$ Med 1995;333:589-90.

101 Begg C, Cho M, Eastwood S, et al. Improving the quality of reporting of randomized controlled trials. The CONSORT statement. $\mathcal{F} A M A$ 1996;276:637-9. 